Yakovleva 0., Yakovlev Yu., Toumanskiy V.

\title{
CHEMICAL ENGINEERING SYSTEMS MODELING AND EFFICIENCY ANALYSIS OF HEAT AND MASS EXCHANGE
}

Запропоновано методику топологічного моделювання хіміко-технологічних систем на основі парної взаємодії потоків. Таке уявлення виробничих схем дає можливість формалізувати їх структуру і створити мову опису, що дозволяе розробляти програмне забезпечення для створення математичної моделі. Визначені інтегральні характеристики для оцінки ефективності тепломасообміну в елементах системи. Виконано перевірку на адекватність методу моделювання.

Ключові слова: виробнича схема, топологічне і математичне моделювання хіміко-технологічних систем, ефективність тепломасообміна.

\section{Introduction}

For industrial manufacturing effective use of material and energy resources is becoming increasingly important in Ukraine, since the energy intensity of Ukrainian industrial manufacturing and the social services is $2-3$ times higher than global indicators. In the structure of energy consumption by industry sectors of Ukraine, metallurgy, chemical, petrochemical and gas industry totally are $60 \%$. Engineering systems of operating enterprises were created at the time of relatively cheap energy. At present, most of them require significant modernization in order to improve the energy efficiency resources use. Any modernization of manufacturing is not conceivable without a preliminary analysis of its energy efficiency.

The energy efficiency of chemical engineering systems depends on correctness of the choice of the main regime system parameters and the type of its process flow diagram. A modern approach to solving targeted problems because of the complexity of such systems is possible only on the basis of modern methods of mathematical modeling and optimization. Process modeling of the chemical engineering systems involves the use of a system approach for studying the full process flow diagram of the obtaining products entire process and the integrated optimization of energy-saving and environmentally friendly technologies. Over the past 20 years, ideology and software have been developed, which allow to solve problems both improving the technology quality and significantly increasing the production energy efficiency. Therefore, improving the modeling techniques and analyzing the efficiency of heatenergy in the industry is an actual task.

\section{The object of research and its technological audit}

The object of research is the chemical engineering system and heat and mass exchange processes that take place in it. In engineering practice, systems are represented by process flow diagrams. Process flow diagram of any modern production represents a finite set of devices, combined by pipelines networks. A graphic view is a network of lines connecting devices. This stylization of process flow diagrams allows getting a general idea about the equipment combination in the engineering system.

The lack of standardization in the graphical representation of engineering systems does not allow to create a general logic for reading out graphic information and then processing it with software. There is a need to work out the rules that allow to match the engineering systems with its topological representation in the form of networks, combined by elements for determining the heat and mass exchange processes in the system.

\section{The aim and objectives of research}

The aim of research is to develop the modeling principles and system analysis of heat and mass exchange efficiency and to create engineering techniques for constructing mathematical descriptions of complex chemical engineering systems.

To achieve this aim you need to:

1. Elaborate the rules for transforming chemical engineering systems into its topological representation.

2. Select efficiency criteria for the heat and mass exchange processes; to develop models of mass exchange and heat exchange networks of chemical engineering system.

3. Develop integrated topological and mathematical models of the heat and mass exchange network of the chemical engineering system.

4. Check for adequacy of the developed Heat Exchanger Network (HEN) and Mass Exchanger Network (MEN) modeling views.

\section{Research of existing solutions of the problem}

In the 90 s of the last century, an attempt to develop generalized representation about engineering systems, named as Heat Exchanger Network (HEN) and Mass Exchanger Network (MEN) [1-4].

This approach allows not only to present the process flow diagram, but also to create a language for software that allows to develop system models using the graphic view [5-9].

Today leading design and research institutes, engineering firms and manufacturing enterprises widely use computer 
systems of engineering systems modeling. Software allows to «assemble» engineering systems, and perform multivariate calculations, to solve optimization problems, and so on.

4.1. Analysis of software intended for engineering systems modeling. Currently, the best systems of engineering systems modeling in the world are considered PRO-2 [5] and HYSYS [6]. GIBBS [7] (development of specialists united in LLC «Топэнергобизнес», Moscow, Russia) and «ГазКондНефть» (development by the team of specialists from the Institute of Gas of the National Academy of Sciences, Kyiv, Ukraine) deserve attention of the other analogues [8]. There are a number of other simpler and less universal modeling systems, which are practically not used at present. In [9], the capabilities of modern simulation software are presented.

PRO-2 [5]. This system was created by the American company «Invensys SimSci-Esscor». The PRO-2 system is considered as the most powerful and developed in the world.

Advantages of PRO-2:

- system includes all types of equipment and all known calculation methods;

- system allows to add your own algorithms, in the built-in «Fortran» programing language;

- development of the WINDOWS-version and the

PROVISION interface greatly facilitated the work with the system.

The disadvantages of the system include:

- its complexity and the fact that an expert is required as a end-user;

- impossibility of interface russification; built-in FORT-

RAN language use, which complicates the system development in the WINDOWS environment.

HYSYS [6]. This system was created by the American company «Aspen Technology, Inc.» and is a WINDOWSversion, which now replaces the very popular DOS-version of HYSIM [10]. The main advantage of the HYSYS system is that the WINDOWS version is reworked in $\mathrm{C}++$. It is fully integrated and allows to model complex systems with pipeline networks, preparation and processing facilities, etc. The HYSYS provides the ability to simulate a nested hierarchical system structure, which is important for linking the operation of individual productions on a plant scale. The end-user interface is conveniently organized, perhaps the most convenient from all analyzed systems - the entire environment is developed on spreadsheets that easily exchange data through the clipboard with WINDOWS applications (for example, with Excel). Another advantage is that system has the best algorithm for rectification columns calculating - it is very quickly solved and very stable. Taking into account the prospects and the pace of development HYSYS chemical systems modeling software is recognized as the best one.

In practice, engineering system modeling can be applied, first, for designing new fields and designing new engineering systems. It is very effective to apply engineering system modeling in the solutions development for the technology reconstruction and modernization. However, mathematical models of the best software PRO-2 and HYSYS require significant expert task replenishment by engineering studies of the system elements structure.

4.2. Energy integration into production cycle as energy saving source for system approach. Any chemical engineering system can be matched with a topological representation that stylizes the system under the HEN-MEN [11-16].
With such a replacement of real objects and connections, the most important is observance of the correspondence that determines the graphic model adequacy to the real system.

One of the challenges facing software in the systems analysis is the qualitative improvement of energy resources use that is embedded in the system (energy integration). The problem formulation leads to the synthesis (structure modification) of the system [11-16]. Change of the system structure leads to the heat exchangers networks replenishment. One of the methods for synthesis problem solving is the pinch analysis use [17-19]. Pinch analysis allows to integrate heat streams within the production cycle.

Together with software use, by changing the system structure, it can find ways to reduce energy consumption from 30 to $50 \%$ [19].

In [20], a computer simulation of the basic engineering system for the production of bioethanol from lignocellulose was carried out using the Aspen Plus, which is developed by the American company Aspen Tech Inc. This software is analyzed the options for integrating thermal processes within the production cycle and carried out the synthesis of energy-saving process flow diagram for the bioethanol production.

Comparison of data obtained as a result of system modeling and the base production system shows that:

- bioethanol production from 1 ton of dry wood increased by $23.8 \%$;

- the specific energy consumption for the 1 liter of bioethanol production is decreased by $25 \%$.

Pinch-analysis, as a way of combining energy levels, allows to achieve certain successes in the heat integration in industrial manufacturing. However, the heuristic nature of the rules proposed by Linnhoff and Smith does not allow to unequivocally answer the question: «Is this the best way to combine energy levels?» Its number can reach huge values, and pinch analysis does not give a clear criterion for choosing the best way to combine energy levels.

\section{Methods of research}

Modern chemical manufacturing is chemical engineering system, consisting of a large number of devices and technological connections between them. For all the complexity of chemical engineering systems, there are typical connections between devices, which integrate them into a single system. They include: serial connection, parallel, sequential-bypass (bypass), recirculation and loop connections [21].

The way finiteness of combining devices in the chemical engineering systems allows to do topological representations to their description and, as a result, the mathematical apparatus of graph theory [21]. In relevance with noted, it seems advisable to introduce a number of definitions which will be used in the future:

1. A line connecting two points will be called a branch.

2. Any point combining at least two branches will be called a node.

3. Any union of branches along which a stream moves that have inputs and outputs for a stream will be called a network.

4. Any union of branches along which a stream moves that has only one input for a stream will be called an ordered network. 
5. A node combining at least three branches of the same network will be called a mixing node or an element within a network exchange of energy. In this case, the measures of energy moving along the branches of the streams must be different in magnitude.

6. The combining of no more than two branches of different networks, designed to organize the exchange of energy between them, will be called an element of the inter-network exchange of energy.

7. The network without input and output for the flow, designed to organize the transfer of energy through the elements of interworking to other networks, will be called a circuit.

The introduced definitions allow to describe the structure of the chemical engineering system, understanding under devices «black boxes», combined by the described methods. In reality, the machines themselves are quite complex systems and they can also be considered as chemical engineering system [21].

One of the key formal thesis used in this work is the assumption that it is possible to represent the streams combined interaction in the system elements by a set of pair interactions. This assumption is based on the possibility of representing a function of several variables by a superposition of functions of two variables [21]. The proposed process flow diagram development is something between the generally accepted developing of the system topology by the so-called «circuit solution» and the processes description in the system elements. A number of requirements remain with the introduced system representation.

Logic of engineering representations about system topology. Pipelines, which are a system of combining devices, are represented by connections. Devices themselves are represented as objects in which the streams pair interaction occurs.

Features of the concept of processes (physical representations). In this work, this circumstance is taken into account by introducing the concepts of mass exchange and heat exchange efficiency in the system.

In this case, it is necessary to take into account that the constructions themselves in the adopted logic should be carried out in accordance with the «schematic solution» and with the expert requirements. The role of the expert is not only to verify the correspondence between the schematic solution and the topological representation of the system. It is also necessary to determine the directions of mass and energy streams and the conditions for single-valuedness (the parameters regime at the input and output).

This assumption allows to present the real device of the chemical engineering system, which has several inputs and outputs for streams, a set of several elements integrated in a subsystem. To ensure the principle of pairing interaction, each of the elements has two inputs and two outputs (Fig. 1).

As an example, let's consider the process flow diagram of the nitrogen liquefier (Fig. 2). Using the developed rules and definitions, let's transform the process flow diagram of the nitrogen liquefier into topological model, which is shown in Fig. 3.

All elements of the engineering system (Fig. 2) are represented on the topological model (Fig. 3) by rectangles with input and output streams. The dashed line shows conditional streams. Conditional streams are streams with zero flow rate, which preserve the principle of the pairing of interaction in each element.

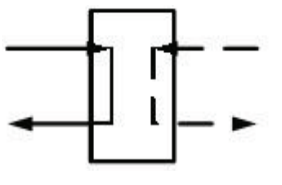

a
Fig. 1. Element of the inter-network: $a$ - energy exchange; $b$ - mass exchange

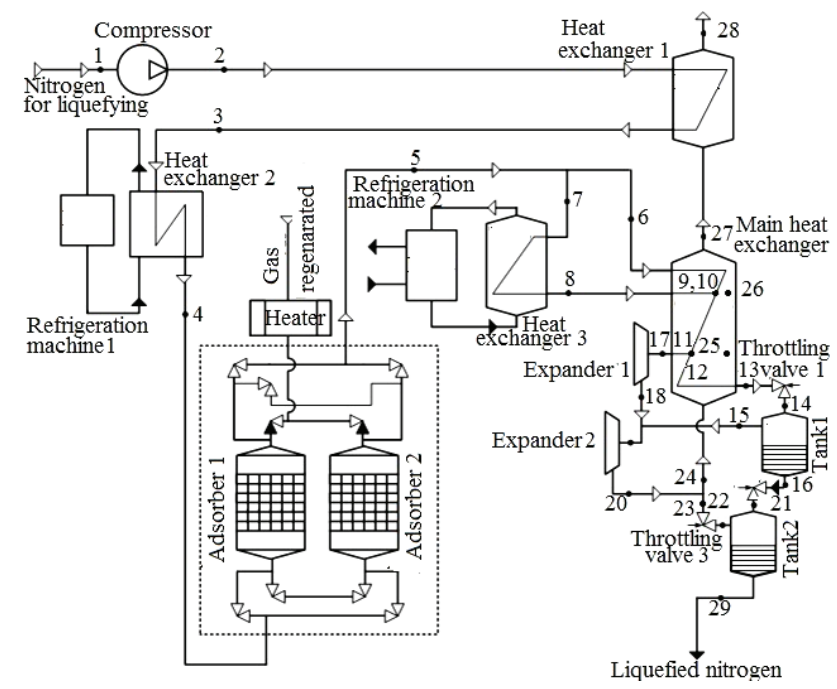

Fig. 2. Process flow diagram for nitrogen liquefier

The topological model in comparison with the process flow diagram is supplemented by additional elements, which we call conditional one. The main heat exchanger is represented by three elements of the circuit Main Heat Exchanger, Conditional Element 2 and Conditional Element 3. It ensures the principle of pairing interaction, since the Main Heat Exchanger have three outputs and three inputs. In conditional Element 1, the nitrogen stream from the adsorber is divided into two streams: one part is sent for cooling in the Refrigeration Machine, and the other part is sent to the Heat Exchanger 3. In the Conditional Element 4, the main stream from Main Heat Exchanger and the stream from the Heat Exchanger 3 are mixed. In the Conditional Element 5, the main stream is divided into two parts. The expander stream enters the expansion in Expander 1, and the remaining part of the main stream for cooling in the Conditional Element 3. In Conditional Element 6, saturated nitrogen vapors from the Tank 1 and the stream after expansion in Expander 1 are mixed, and they enter Expander 2. In Conditional Element 7, the nitrogen stream after expansion in Expander 2 is mixed with saturated vapor after throttling in Throttling valve 3 and feed main heat exchanger for cooling of the direct flow. Conditional Elements: 4, 6 and 7 are the nodes of the stream mixing, and 1 and 5 are the nodes of the stream separation.

The topological model of the process flow diagram (Fig. 3) allows to develop a language for its description that is acceptable for software development which is able to create mathematical models of chemical engineering systems. 


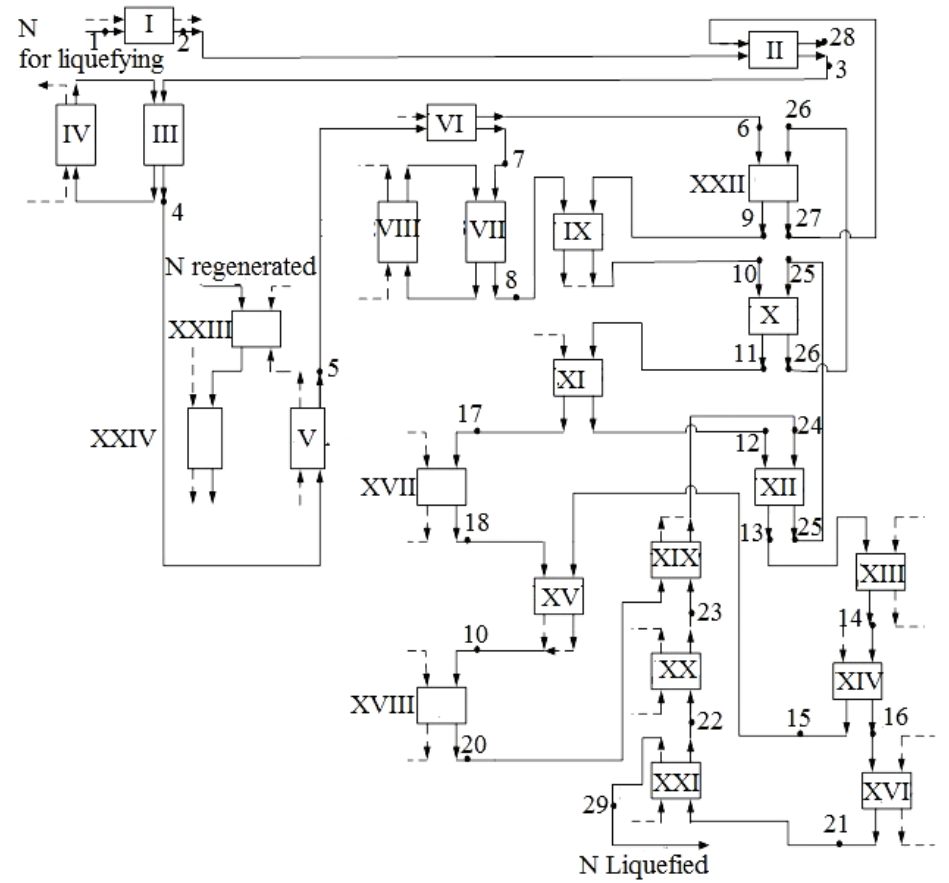

Fig. 3. Topological model of the technological scheme of nitrogen liquefier: I - compressor; II, III, VII - heat exchangers; IV, VIII - refrigerating machines; XVII, XVIII - turboexpanders; XIII, XVI, XX - throttling valves; XIV, XXI - tanks; XXIV, V - adsorbers; XXIII - heater; XXII - main heat exchanger; VI, X, XII, IX, XI $\mathrm{XV}$, XIX - conventional elements;

technological stream; -..----- conditional stream

In [22], for the element shown in Fig. $1, b$ of the topological representation of the system element for mass exchange between networks, its mathematical model is written, the principles of MEN models creating for chemical engineering systems are developed, and the concept of the flow rate concentration and the mass exchange efficiency in the system elements is introduced.

The proposed modeling method allows the problem for chemically reacting media to be represented as a mass exchange problem. Within the framework of the previously adopted definitions, a complete process flow diagram for the chemical products manufacturing can be represented in the form of a topological model for which it will write a system of equations for the concentrations balance using the introduced concepts of flow rate concentration and mass exchange efficiency. This mathematical model allows to:

- develop a software environment that generates a sys-

tem model based on its topological representation;

- analyze various options for implementing the process

flow diagram for obtaining finished products;

- synthesize the optimal, energy-saving manufacturing process.

For the development of the HEN model of chemical production, an heat exchange element intended for exchange between networks (Fig. 4) is considered in [23], in which a pair interaction of the streams takes place.

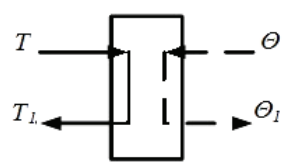

Fig. 4. Element of heat exchange between networks
Having identified the energy stream with the concept of total enthalpy, it is easy to write down the energy balance for an element in the form:

$$
\begin{aligned}
& H-H_{1}=I_{1}-I \Rightarrow C P_{\text {heating }} \cdot\left(T_{1}-T\right)= \\
& =C P_{\text {heated }} \cdot\left(\Theta-\Theta_{1}\right),
\end{aligned}
$$

where $H$ - total enthalpy for the flow with a large value of the energy measure; $I$ - total enthalpy for the stream with a smaller value.

Denote $T, \Theta$ as energy measures, a $C P_{\text {heating, }}$ $C P_{\text {heated }}$ - as the heat capacities of the heating and heated streams, respectively.

The «one» index defines the values of the total enthalpy and temperatures at the exit from the element, the values without indices refer to the input of the stream. Consider the $Q T$ diagram of the element of the heat exchange network (Fig. 5). If at the inputs of element a measures and the flow rate heat capacities of the stream are specified, then the average enthalpy temperature $T_{\Sigma}$ for the element can be determined:

$$
T_{\Sigma}=\Theta_{\Sigma}=\frac{T \cdot C P_{\text {heating }}+\Theta \cdot C P_{\text {heated }}}{C P_{\text {heating }}+C P_{\text {heated }}} .
$$

The amount of energy that the stream gives with a large energy potential, until the thermodynamic equilibrium is reached, is determined:

$$
\begin{aligned}
& Q_{1}=T \cdot C P_{\text {heating }}- \\
& -\frac{T \cdot C P_{\text {heating }}+\Theta \cdot C P_{\text {heated }}}{C P_{\text {heating }}+C P_{\text {heated }}} \cdot C P_{\text {heating }} .
\end{aligned}
$$

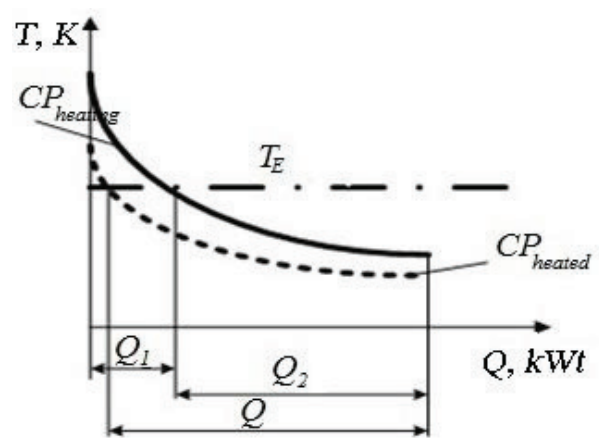

Fig. 5. QT-diagram of element of heat exchange between networks

The amount of energy that a stream with a lower energy potential receives before reaching thermodynamic equilibrium is determined:

$$
Q_{2}=\frac{T \cdot C P_{\text {heating }}+\Theta \cdot C P_{\text {heated }}}{C P_{\text {heating }}+C P_{\text {heated }}} \times C P_{\text {heated }}-\Theta \cdot C P_{\text {heated }} .
$$

The maximum possible amount of energy that can be exchanged between streams:

$$
\begin{aligned}
& \Delta \Phi=Q_{1}+Q_{2}=2 \cdot C P_{\text {heating }} \cdot C P_{\text {heated }} \cdot \frac{T-\Theta}{C P_{\text {heating }}+C P_{\text {heated }}}= \\
& =2 \cdot C P_{\text {heating }} \cdot \frac{1}{1+\alpha}(T-\Theta),
\end{aligned}
$$


where

$$
\alpha=\frac{C P_{\text {heating }}}{C P_{\text {heated }}} .
$$

$\Delta \Phi$ is taken as the limiting energy potential for the system element. Let's determine the ratio of the actually transferred amount of energy $Q$ to the energy potential:

$$
\begin{aligned}
& \eta_{E}=\frac{Q}{\Delta \Phi}=\frac{C P_{\text {heating }}+C P_{\text {heated }}}{2 \cdot C P_{\text {heated }}} \cdot \frac{T-T_{1}}{T-\Theta}= \\
& =\frac{1+\alpha}{2} \cdot \frac{T-T_{1}}{T-\Theta}=\frac{1+\alpha}{2} \cdot \varphi,
\end{aligned}
$$

where

$$
\varphi=\frac{T-T_{1}}{T-\Theta} .
$$

The value of the ratio of the actually transferred energy to the energy potential will be called the energy exchange efficiency $\eta_{E}$, and the ratio of the temperature change in the element to the difference in temperatures at the input is the temperature change efficiency $\varphi$.

The introduced definitions allow to formulate a system of equations connecting the temperatures at the output from the element with the value of these quantities at the input to it:

$$
\begin{aligned}
& T-T_{1}=C P_{\text {heating }} \cdot \frac{2}{1+\alpha} \cdot \eta_{E} \cdot(T-\Theta)=\varphi \cdot(T-\Theta), \\
& \alpha \cdot\left(T-T_{1}\right)=\Theta_{1}-\Theta .
\end{aligned}
$$

At the same time, the amount of energy exchanged by the network will be determined:

$$
\begin{aligned}
& Q=C P_{\text {heating }} \cdot\left(T-T_{1}\right)=C P_{\text {heating }} \cdot \frac{2}{1+\alpha} \times \\
& \times \eta_{E} \cdot(T-\Theta)=C P_{\text {heating }} \cdot \varphi \cdot(T-\Theta) .
\end{aligned}
$$

Within the framework of accepted definitions, any engineering system can be represented as a network model for which we will write the system of equations taking into account the change in the energy measure efficiency and solve two problems:

- to determine the energy measures at the nodes of

the system;

- to determine the efficiency of energy exchange in the nodes of the system.

The main advantage of networks energy exchange representations in systems is the ability to take into account a large number of factors affecting energy and resource saving even at the design phase.

\section{Research results}

In [24], a checking for adequacy of the developed representations of HEN-MEN modeling is made. The process flow diagram of the synthesis for urea production (Fig. 6), implemented at one of the operating enterprises, are transformed into a generalized topological HEN-MEN model.

The computer simulation procedure for the synthesis unit is carried out in several phases.
At the first phase, the process flow diagram of the synthesis block for the urea production is considered.

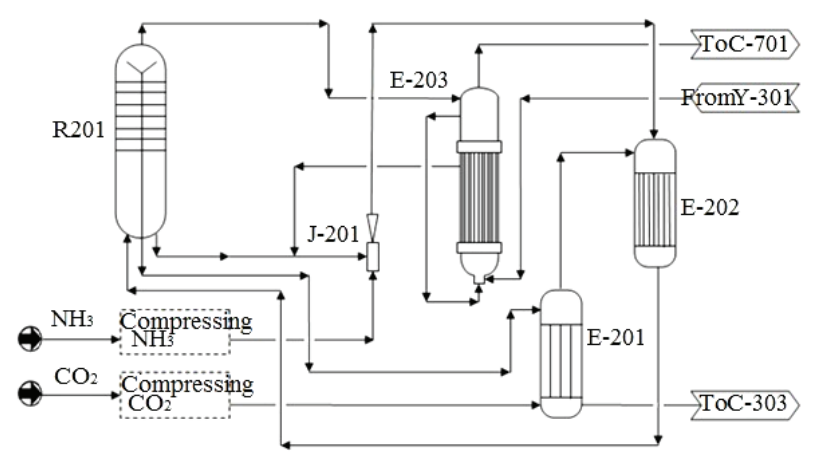

Fig. 6. Process flow diagram for the synthesis of urea production: R-201 - high-pressure synthesis column; E-201 - Stripper; E-202 - high-pressure condenser; E-203 - scrubber; J-201 - injector; C-303 - low-pressure distillation column; C-701 - absorber; V-301 - carbon ammonium salts tank

In the second phase, using the principles of topological models development of mass-exchange networks for process flow diagram, formulated in [21], the engineering system is transformed into its topological MEN representation. In other words, the synthesis unit for urea production is aligned with its topological equivalent, shown in Fig. 7.

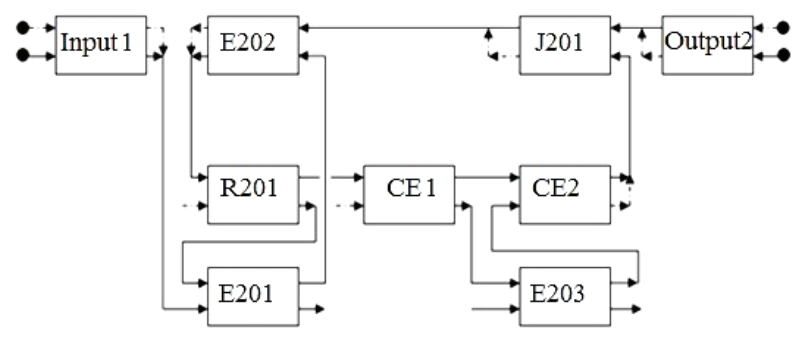

Fig. 7. MEN topology for process flow diagram of synthesis unit: CE1, CE 2 - conditional elements;

$\longrightarrow$ - technological stream; --.--.--- - conditional stream

The third phase is dedicated to the topological NEN model development of the Synthesis Unit. As it is noted earlier, in chemical engineering systems, the processes in the system elements are synthesized with the heat supply and heat removal. Therefore, the topological MEN model of process flow diagram for the synthesis unit must be replenished with networks of utility streams (Fig. 8).

The fourth phase involves the topological HEN-MEN model development of the synthesis unit. It is shown in $[22,23]$ that the streams of the mass exchange network represent a single medium interacting with the streams of external heat utilities. Let's combine them into one heat exchange network. So the second network is external utilities of streams.

This approach allows to preserve the principle of pairing interactions in the chemical engineering system elements. The streams distribution in the mass-exchange network can be determined from the parameters of the mass-exchange processes model. In Fig. 9 shows the combined topological HEN-MEN model of the synthesis unit.

Elements that have no external sources or heat sinks can be represented in the model as nodes for streams 
mixing and distributing taking into account endo- and exothermic, chemical, and physical processes. Therefore, the synthesis column R201 in Fig. 9 is represented by the distribution node, rather than the system element.

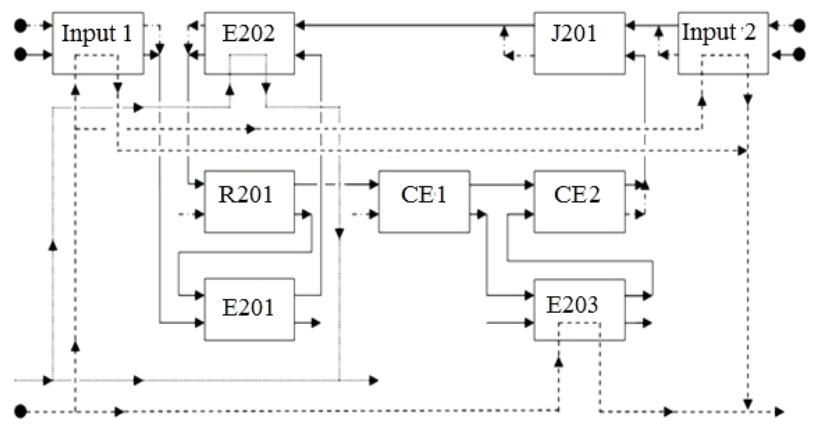

Fig. 8. HEN topology for process flow diagram of synthesis unit: CE1, CE 2 - conditional elements

$\longrightarrow$ - technological stream; $\longrightarrow$ - vapor; --------- - water

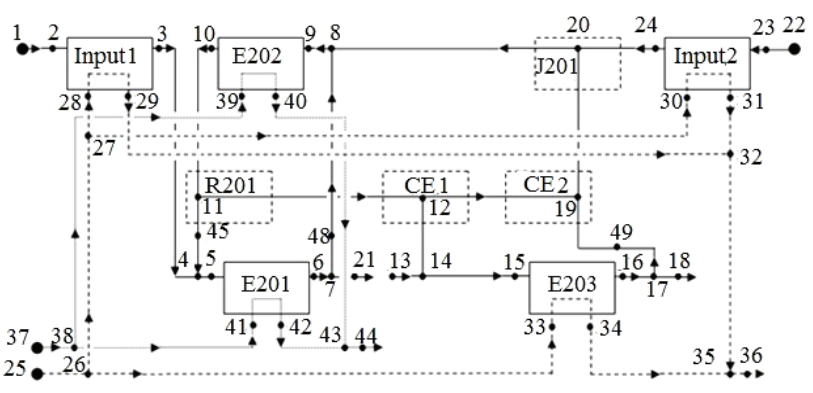

Fig. 9. HEN-MEN topology of process flow diagram for synthesis unit: CE1, CE 2 - conditional elements;

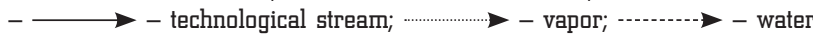

As noted in part 5, the accepted principles of the topological representation of the system and processes in their elements by the streams pair interaction allow to:

- programmatically develop a heat and mass exchange processes closed model;

- determine the processes efficiency in the system elements;

- find the distribution of streams on its branches and temperatures in the nodes of the networks.

Such representations make it possible to develop a software environment that generates a mathematical model of a system based on its topological representation, to analyze various options for implementing process flow diagram for the production of finished products, synthesize an optimal, energy-saving, production process variant.

Using simulation software developed by the German company NETWORK SOLUTION DEVELOPMENT CO. and received for testing, a numerical experiment is carried out. Table 1 shows the results of a numerical experiment.

Numerical experiment is conducted with heat and mass exchange efficiency, values is shown in the Table 2.

The mass flow rates obtained in the numerical experiment corresponded to their values at the reference points of the process flow diagram for the design mode. The error in determining the streams did not exceed $2.4 \%$ on the branches, and the temperature at the nodes strictly corresponded to the technological regulations.
Table 1

Calculated values of mass flow rate and technological stream temperature at various points in the synthesis unit

\begin{tabular}{|l|c|c|c|}
\hline Name of technological stream & $\begin{array}{c}\text { Number of } \\
\text { points accord- } \\
\text { ing to Fig. }\end{array}$ & $\begin{array}{c}\text { Mass flow } \\
\text { rate, } \\
\text { kg/sec }\end{array}$ & $\begin{array}{c}\text { Stream } \\
\text { tempera- } \\
\text { ture, }\end{array}$ \\
\hline Input to R-201 from E-202 & 10 & 40.938 & 167 \\
\hline Output from R-201 to E-201 & 45 & 37.296 & 183 \\
\hline Output from R-201 to E-203 & 46 & 3.6425 & 183 \\
\hline Output from R-201 to J-201 & 47 & 0 & - \\
\hline Input to E-201 from R-201 & 45 & 37.296 & 183 \\
\hline $\begin{array}{l}\text { Input to E-201 from compress- } \\
\text { ing node CD2 }\end{array}$ & 3 & 8.8344 & 100 \\
\hline Output from E-201 to E-202 & 48 & 24.387 & 180 \\
\hline Output from E-201 to C-303 & 21 & 21.743 & 180 \\
\hline Output from E-202 to E-201 & 48 & 24.387 & 180 \\
\hline Output from E-202 to J-201 & 20 & 16.551 & 104.5 \\
\hline Output from E-202 to R-201 & 10 & 40.938 & 167 \\
\hline $\begin{array}{l}\text { Input to E-203 from tank } \\
\text { V-301 }\end{array}$ & 13 & 7.1125 & 69 \\
\hline Input to E-203 from R-201 & 46 & 3.6425 & 183 \\
\hline Output from E-203 to J-201 & 49 & 9.9953 & 160 \\
\hline Output from E-203 to L-701 & 18 & 0.75972 & 160 \\
\hline Output from J-201to R-201 & 47 & 0 & - \\
\hline Output from J-201to E-203 & 49 & 9.9953 & 160 \\
\hline $\begin{array}{l}\text { Input to J-201 from compres- } \\
\text { sion node NH3 }\end{array}$ & 24 & 6.5556 & 20 \\
\hline Output from J-201to E-202 & 20 & 16.551 & 104.5 \\
\hline
\end{tabular}

Table 2

Heat and mass exchange system elements efficiency values

\begin{tabular}{|c|c|c|}
\hline $\begin{array}{c}\text { Name of system } \\
\text { element }\end{array}$ & $\begin{array}{c}\text { Heat exchange } \\
\text { efficiency }\end{array}$ & $\begin{array}{c}\text { Mass exchange } \\
\text { efficiency }\end{array}$ \\
\hline B-201 & 0 & 0.912 \\
\hline E-201 & 0.8675 & 0.28 \\
\hline E-202 & 0.1888 & 0.596 \\
\hline E-203 & 0.4724 & 0.591 \\
\hline J-201 & 0 & 0.664 \\
\hline
\end{tabular}

\section{SWOT analysis of research results}

Strengths. The strength of this research is the representation of the topological model and its elements, the developed rules for creating flowcharts, the symbols of the devices and the techniques of chemical engineering systems representation. This allows any engineering system to transform into its topological representation in the form of networks, combined by elements with a streams pair interaction for organizing the heat and mass exchange processes in the system.

In contrast to analogs [5-10], in the mass exchange simulation, the transition from the chemical problem to the physical one is applied. The flow rate characteristics are used instead of the volume concentrations of the reacting components, which are difficult to determine in the production conditions at the given nodes of the chemical engineering system. 
The created mathematical models of heat- and massexchange networks for chemical industry are proof that the analysis and synthesis problems of chemical engineering system can be solved with a minimum of information about the system. Having initial input data, the data at the output from the element is obtained, without affecting the processes occurring in it. A communication function is provided that allows processing the experimental data. This concept allows to perceive information in the form of algorithms suitable for software development, with the goal of automating the creation for a system of equations.

Weaknesses. The need for expert judgment in determining the direction of mass and energy streams and the value of the regime parameters at the input and output to the system. To increase the reliability of mathematical modeling for processes in chemical engineering system in a numerical experiment, it is necessary to know the thermophysical properties of substances in a wide range of temperatures and pressures. However, so far there are no sufficiently universal equations of state and they are still poorly adapted for specific practical applications.

Opportunities. Further research objectives are related to the analysis, design and synthesis of chemical engineering system. System analysis or calculation verification allows to conduct analysis, determining the system's energy potential. The system design takes into account possible environmental impacts, safety, etc. Synthesis of the system arises as a subordinate task in the system design and analysis and allows, by changing its structure and technological parameters, to increase energy efficiency

Threats. The complexity of using this research lies in the lack of interest of Ukrainian enterprises in the efficiency analysis for energy-intensive processes of chemical technology. It requires additional costs, and the economic effect form recommendations on the structural and parametric optimization for the process flow diagram will be obtained only after the production modernization.

In the leading countries, many energy companies realized that loss of profit due to a decrease in demand could be compensated by diversification of economic activities, including energy audit and energy management.

However, it is noteworthy that over the past few years the energy intensity indicator remains almost unchanged. Meanwhile, the Energy Strategy of Ukraine for the period until 2030 provides that after 15 years the energy intensity in the country should be 0.22 and it will take about $\$ 24$ billion.

To achieve this result, not only money is important, it is necessary to radically revise the approaches to the organization of production processes. Otherwise, it is impossible to make such breakthrough.

\section{Conclusions}

1. For the first time, rules are made for topological models development for mass exchange and heat exchange networks for process flow diagram of chemical engineering systems under the assumption of the streams interaction in the system elements.

2. The criteria for the mass exchange and energy exchange efficiency, system elements for analyzing its performance in general, are determined. The principles of system development have been created and mathematical models of mass-exchange and heat-exchange networks of chemical production based on the balance equations and heat and mass transfer efficiency have been represented.

3. The principles of system development are created and combined topological and mathematical HEN-MEN models for the urea synthesis unit are created too. The developed concept allows to perceive information in the form of algorithms acceptable for software development, in order to automate the scheme for constructing a system of equations.

4. The verification of the adequacy for the developed HEN-MEN representations of modeling is carried out on the example of the process flow diagram of the synthesis unit for urea production. The conducted numerical experiment allows to determine the energy potential of the engineering system and pointed out the possibilities of increasing the energy efficiency of production by using the heat of the general production cycle.

5 . The possibility of including an additional circuit in the structure of the engineering system for the Urea production for heating the technological stream, combining the synthesis column R201, an additional heat exchanger and a water condenser is considered. An increase in the stream temperature at the inlet to the evaporation unit in accordance with the technological regulations in the range of $91 \ldots 106{ }^{\circ} \mathrm{C}$ reduces the low-pressure steam flow rate by $1.2 \mathrm{t} / \mathrm{h}$.

\section{References}

1. Yee, T. F. Simultaneous optimization models for heat integration I. Area and energy targeting and modeling of multi-stream exchangers [Text] / T. F. Yee, I. E. Grossmann, Z. Kravanja // Computers \& Chemical Engineering. - 1990. - Vol. 14, № 10. P. 1151-1164. doi:10.1016/0098-1354(90)85009-y

2. Yee, T. F. Simultaneous optimization models for heat integration - II. Heat exchanger network synthesis [Text] / T. F. Yee, I. E. Grossmann // Computers \& Chemical Engineering. 1990. - Vol. 14, № 10. - P. 1165-1184. doi:10.1016/00981354(90)85010-8

3. Ji, S. Design of Crude Distillation Plants with Vacuum Units. II. Heat Exchanger Network Design [Text] / S. Ji, M. Bagajewicz // Industrial \& Engineering Chemistry Research. - 2002. Vol. 41, № 24. - P. 6100-6106. doi:10.1021/ie011041m

4. Yan, Q. Synthesis of highly controllable heat integration systems [Text] / O. Yan, J. Xiao, Y. Huang // Journal of the Chinese Institute of Chemical Engineers. - 2006. - Vol. 37, № 5. - P. 457-465.

5. SimSci PRO/II [Electronic recourse] // Schneider Electric Software, LLC. - 2015. - Available at: \www/URL: http:// software.schneider-electric.com/products/simsci/design/pro-ii/

6. Optimize Hydrocarbon Processes with Aspen HYSYS ${ }^{\circledR}$ [Electronic recourse] // Aspen Technology, Inc. - 2016. - Available at: \www/URL: http://www.aspentech.com/hysys/

7. Zagruzka informatsii o programme [Electronic recourse] // Modelirovanie v neftegazovoi otrasli. GIBBS. - 2014. - Available at: \www/URL: http://www.gibbsim.ru/node/33

8. Process Simulation Software for Natural Gas and Oil Engineering [Electronic recourse] // Scientific \& Technical Firm THERMOGAS Ltd. - 2016. - Available at: \www/URL: http://thermogas.kiev.ua/Products.htm

9. Gartman, T. R. Analiticheskii obzor sovremennyh paketov modeliruiushchih programm dlia komp'iuternogo modelirovaniia himiko-tehnologicheskih sistem [Text] / T. P. Gartman, F. S. Sovetin // Uspehi v himii i himicheskoi tehnologii. 2012. - Vol. 26, № 11 (140). - P. 117-120.

10. HYSIM [Electronic recourse] // Water Resource Associates. 2015. - Available at: \www/URL: http://www.watres.com/ software/HYSIM/

11. Rohani, Y. A. A Novel Application of Pinch Technology in Air Pollution Analysis [Text] / Y. A. Rohani, A. R. Naderpour, B. B. Dabir, M. H. Panjehshahi // Proceedings of International Conference on Environmental Science and Technology(ICEST 2011). - 2011. - Vol. 6. - P. 430-439. 
12. Chegini, S. Modification of Preheating Heat Exchanger Network in Crude Distillation Unit of Arak Refinery Based on Pinch Technology [Text] / S. Chegini, R. Dargahi, A. Mahdavi // Proceedings of the World Congress on Engineering and Computer Science. - 2008. - P. 123-127.

13. Hasan, M. M. F. Synthesis of heat exchanger networks with nonisothermal phase changes [Text] / M. M. F. Hasan, G. Jayaraman, I. A. Karimi, H. E. Alfadala // AIChE Journal. - 2009. Vol. 56, № 4. - P. 930-945. doi:10.1002/aic.12031

14. Hasan, M. M. F. Synthesis of Heat Exchanger Networks Involving Phase Changes [Text] / M. M. F. Hasan, I. A. Karimi, H. E. Alfadala // Proceedings of the $1^{\text {st }}$ Annual Gas Processing Symposium. - 2009. - P. 185-192.

15. Paengjuntuek, W. Heat Recovery from Process to Process Exchanger by Using Bypass Control [Text] / W. Paengjuntuek C. Kiatpiriya, H. Phungrassami, P. Saikhwan // World Applied Sciences Journal. - 2009. - Vol. 6, № 7. - P. 1008-1016.

16. Li, L.-J. Separation network design with mass and energy separating agents [Text] / L.-J. Li, R.-J. Zhou, H.-G. Dong, I. E. Grossmann // Computers \& Chemical Engineering. 2011. - Vol. 35, № 10. - P. 2005-2016. doi:10.1016/j.compchemeng.2010.10.013

17. Linnhoff, B. Synthesis of heat exchanger networks: II. Evolutionary generation of networks with various criteria of optimality [Text] / B. Linnhoff, J. R. Flower // AIChE Journal. - 1978. Vol. 24, № 4. - P. 642-654. doi:10.1002/aic.690240412

18. Linnhoff, B. The pinch design method for heat exchanger networks [Text] / B. Linnhoff, J. R. Flower // Chemica Engineering Science. - 1983. - Vol. 38, № 5. - P. 745-763. doi:10.1002/aic.690240412

19. Foo, C. Y. Synthesis of mass exchange network for batch processes - Part I: Utility targeting [Text] / C. Y. Foo, Z. A. Manan, R. M. Yunus, R. A. Aziz // Chemical Engineering Science. 2004. - Vol. 59, № 5. - P. 1009-1026. doi:10.1016/j.ces.2003.09.043

20. Cardonaalzate, C. Energy consumption analysis of integrated flowsheets for production of fuel ethanol from lignocellulosic biomass [Text] / C. Cardonaalzate, O. Sancheztoro // Energy. - 2006. - Vol. 31, № 13. - P. 2447-2459. doi:10.1016/ j.energy.2005.10.020

21. Kafarov, V. V. Analiz i sintez himiko-tehnologicheskih sistem [Text]: Handbook / V. V. Kafarov, V. P. Meshalkin. - Moscow: Khimiia, 1991. - 432 p.

22. Yakovleva, O. Yu. Modelirovanie massoobmena v HTS [Text] O. Yu. Yakovleva, M. G. Khmelniuk, G. V. Derevianko, Yu. A. Yakovlev // Refrigeration engineering and technology. - 2011. - № 4 (132). - P. 82-86.
23. Yakovleva, O. Yu. Otsenka effektivnosti mezhsetevogo energoobmena [Text] / O. Yu. Yakovlev, M. G. Khmelniuk, A. Yu. Yakovlev // Refrigeration engineering and technology. 2008. - № 6 (116). - P. 25-27.

24. Yakovleva, O. Yu. Modelirovanie i analiz effektivnosti proizvodstvennoi shemy polucheniia karbamida [Text] / O. Yu. Yakovleva, M. G. Khmelniuk, G. V. Derevianko, Yu. A. Yakovlev // Refrigeration engineering and technology. - 2010. - № 4 (132). P. $60-65$

\section{МОДЕЛИРОВАНИЕ ХИМИКО-ТЕХНОЛОГИЧЕСКИХ СИСТЕМ И АНАЛИЗ ЭФФЕКТИВНОСТИ ТЕПЛОМАССООБМЕНА}

Предложена методика топологического моделирования химико-технологических систем на основе парного взаимодействия потоков. Такое представление производственных схем дает возможность формализовать их структуру и создать язык описания, позволяющий разрабатывать программное обеспечение для создания математической модели. Определены интегральные характеристики для оценки эффективности тепломассообмена в элементах системы. Выполнена проверка на адекватность метода моделирования.

ключевые слова: производственная схема, топологическое и математическое моделирование химико-технологических систем, эффективность тепломассообмена.

Yakovleva Olga, PhD, Associate Professor, Department of Refrigeration Plants and Air-Conditioning Systems, V. S. Martynozskyi Educational \& Scientific Institute of Cold, Cryotechnologies and Environmental Energy, Odessa National Academy of Food Technologies, Ukraine, e-mail: osarja@gmail.com, ORCID: http://orcid.org/ 0000-0003-4785-9069

Yakovlev Yuriy, PhD, Associate Professor, Department of Compressors and Pneumatic Units, V. S. Martynovskyi Educational E S Scientific Institute of Cold, Cryotechnologies and Environmental Energy, Odessa National Academy of Food Technologies, Ukraine, e-mail: kapitos2002@yandex.ua, ORCID: http://orcid.org/0000-00024670-6696

Toumanskiy Viktor, PhD, Associate Professor, Department of Compressors and Pneumatic Units, V. S. Martynovskyi Educational $\mathcal{E}$ Scientific Institute of Cold, Cryotechnologies and Environmental Energy, Odessa National Academy of Food Technologies, Ukraine, ORCID: http://orcid.org/0000-0001-5212-3174

\section{Dolya C.}

\section{MODELING OF INTERCITY PASSENGER TRANSPORTATION SYSTEM}

Досліджено засоби проведення оцінювання параметрів ефективності функціонування системи маршрутів пасажирських транспортних систем. Запропоновано послідовність формування транспортної системи міжміського пасажирського транспорту, яка спирається на досягнення науки і практики, та враховує закономірності розподілу транспортних кореспонденцій між містами від транспортної мережі. Доповнено функції тяжіння між містами відповідно до кількості мешканців $і$ купівельної спроможності.

Ключові слова: система марирутів, ефективність перевезень, пасажирські кореспонденції, транспортний прощес.

\section{Introduction}

The role of transport and its infrastructure can't be overemphasized in the overall system of economic relations of any society. Relations between legal entities and individuals, their development and diversity are largely based on information, material, financial and other flows. In this case, physical changes in the location of people are of great importance. For this purpose, passenger transportation systems are being developed and are functioning. 